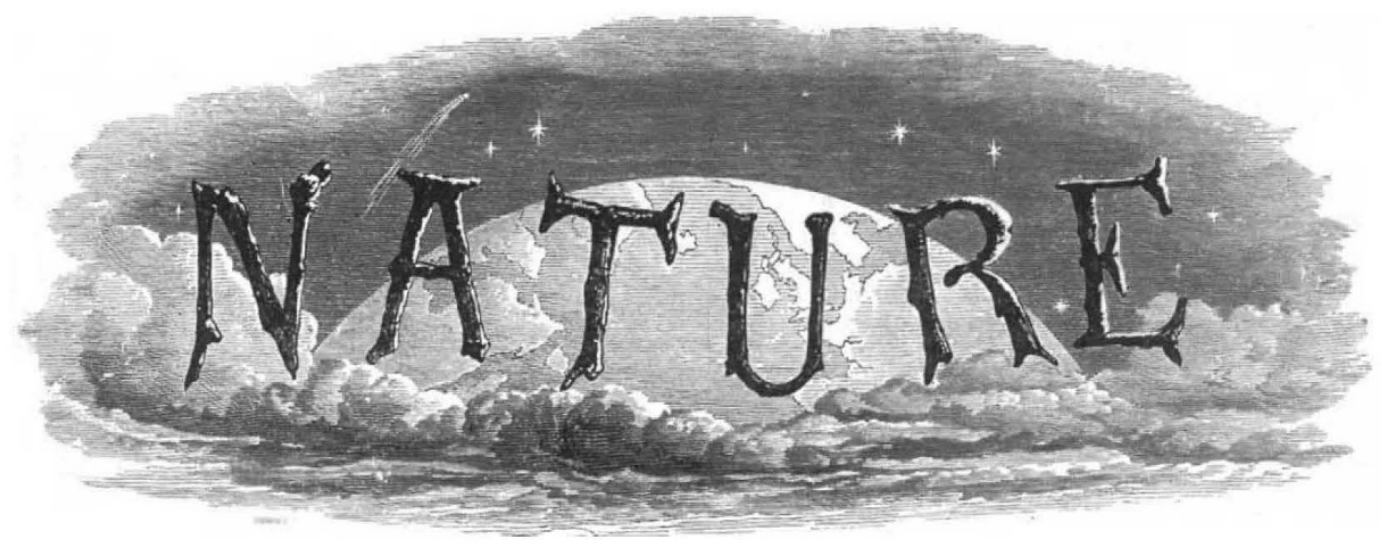

A WEEKLY ILLUSTRATED JOURNAL OF SCIENCE

"To the solid ground

of Nature trusts the mind which builds for aye."-WORDSWORTH

THURSDAY, MAY 6, 1880

\section{THE COMING OF AGE OF THE ORIGIN OF SPECIES ${ }^{\mathrm{T}}$}

$\mathrm{M}^{\mathrm{A}}$

ANY of you will be familiar with the aspect of this small green-covered book. It is a copy of the first edition of the "Origin of Species," and bears the date of its production-the first of October, 1859. Only a few months, therefore, are needed to complete the full tale of twenty-one years since its birthday.

Those whose memories carry them back to this time will remember that the infant was remarkably lively, and that a great number of excellent persons mistook its manifestations of a vigorous individuality for mere naughtiness; in fact there was a very pretty turmoil about its cradle. My recollections of the period are particularly vivid; for, having conceived a tender affection for a child of what appeared to me to be such remarkable promise, I acted for some time in the capacity of a sort of under-nurse, and thus came in for my share of the storms which threatened even the very life of the young creature. For some years it was undoubtedly warm work, but considering how exceedingly unpleasant the apparition of the new-comer must have been to those who did not fall in love with him at first sight, I think it is to the credit of our age that the war was not fiercer, and that the more bitter and unscrupulous forms of opposition died away as soon as they did.

I speak of this period as of something past and gone, possessing merely a historical, I had almost said an antiquarian interest. For, during the second decade of the existence of the "Origin of Species," opposition, though by no means dead, assumed a different aspect. On the par of all those who had any reason to respect themselves, it assumed a thoroughly respectful character. By this time the dullest began to perceive that the child was not likely to perish of any congenital weakness or infantile disorder, but was growing into a stalwart personage, upon whom mere goody scoldings and threatenings with the birch-rod were quite thrown away.

I A Lecture delivered at the Royal Institution, Friday, March Ig. VOL. XXII.-No. 549
In fact, those who have watched the progress of science within the last ten years will bear me out to the full when I assert that there is no field of biological inquiry in which the influence of the "Origin of Species" is not traceable ; the foremost men of science in every country are either avowed champions of its leading doctrines, or at any rate abstain from opposing them; a host of young and ardent investigators seek for and find inspiration and guidance in Mr. Darwin's great work; and the general doctrine of Evolution, to one side of which it gives expression, finds in the phenomena of biology a firm base of operations whence it may conduct its conquest of the whole reaim of nature.

History warns us, however, that it is the customary fate of new truths to begin as heresies and to end as superstitions; and, as matters now stand, it is hardly rash to anticipate that, in another twenty years, the new generation, educated under the influences of the present day, will be in danger of accepting the main doctrines of the Origin of Species with as little reflection, and it may be with as little justification, as so many of our contemporaries, twenty years ago, rejected them.

Against any such a consummation let us all devoutly pray; for the scientific spirit is of more value than its products, and irrationally-held truths may be more harmful than reasoned errors. Now the essence of the scientific spirit is criticism. It tells us that to whatever doctrine claiming our ascent we should reply, Take it if you can compel it. The struggle for existence holds as much in the intellectual as in the physicai world. A theory is a species of thinking, and its right to exist is coextensive with its power of resisting extinction by its rivals.

From this point of view it appears to me that it would be but a poor way of celebrating the Coming of Age of the Origin of Species were I merely to dwell upon the facts, undoubted and remarkable as they are, of its far-reaching influence and of the great following of ardent disciples who are occupied in spreading and developing its doctrines. Mere insanities and inanities have before now swollen to portentouis size in the course of twenty years. Let us rather ask this prodigious change in opinion to justify itself; let us inquire whether anything has happened since 1859 which will explain, on rational grounds, why so many are worshipping that which they burned, and burning 
that which they worshipped. It is only in this way that we shall acquire the means of judging whether the movement we have witnessed is a mere eddy of fashion, or truly one with the irreversible current of intellectual progress, and, like it, safe from retrogressive reaction.

Every belief is the product of two factors : the first is the state of the mind to which the evidence in favour of that belief is presented; and the second is the logical cogency of the evidence itself. In both these respects the history of biological science during the last twenty years appears to me to afford an ample explanation of the change which has taken place; and a bricf consideration of the salient events of that history will enable us to understand why, if the "Origin of Species" appeared now, it would meet with a very different reception from that which greeted it in 1859 .

One-and-twenty years ago, in spite of the work commenced by Hutton and continued with rare skill and patience by Lyell, the dominant view of the past history of the earth was catastrophic. Great and sudden physical revolutions, wholesale creations and extinctions of living bcings, were the ordinary machinery of the geological epic brought into fashion by the misapplied genius of Cuvier. It was gravely maintaincd and taught that the cnd of every geological epoch was signalised by a cataclysm, by which every living being on the globe was swept away, to be replaced by a brand-new creation when the world returned to quiescence. A scheme of nature which appeared to be modelled on the likeness of a succession of rubbers of whist, at the end of each of which the players upset the table and called for a new pack, did not seem to shock anybody.

I may be wrong, but I cloubt if at the present time there is a single responsible representative of these opinions left. The progress of scientific geology has elevated the fundamental principle of uniformitarianism, that the explanation of the past is to be sought in the study of the present, into the position of an axiom; and the wild speculations of the catastrophists, to which we all listened with respect a quarter of a century ago, would hardly find a singlc patient hearer at the present day. No physical geologist now dreams of seeking outside the ranges of known natural causes for the explanation of anything that happened millions of years ago, any more than he would be guilty of the like absurdity in regard to current events.

The effect of this change of opinion upon biological speculation is obvious. For, if there have been no periodical general physical catastrophes, what brought about the assumed general extinctions and re-creations of life which are the corresponding biological catastrophes? And if no such interruptions of the ordinary course of naturc have taken place in the organic, any more than in the inorganic, world, what alternative is there to the admission of Evolution?

The doctrine of Evolution in Biology is the necessary result of the logical application of the principles of uniform:tarianism to the phenomena of life. Darwin is the natural successor of Hutton and Lycll, and the "Origin of Species" the natural sequence of the "Principles of Geology."

The fundamental doctrine of the "Origin of Species," as of all forms of the theory of Evolution applied to biology, is "that the innumerable species, genera, and families of organic beings with which the world is peopled have all descended, each within its own class or group, from common parents, and have all been modified in the course of descent." ?

And, in view of the facts of geology, it follows that all living animals and plants "are the lineal descendants of those which lived long before the Silurian cpoch." 2

It is an obvious consequence of this theory of Descent with Modification, as it is sometimes called, that all plants and animals, however different they may now be, must, at one time or other, have been connected by direct or indirect intermediate gradations, and that the appearance of isolation presented by various groups of organic beings must be unreal.

No part of Mr. Darwin's work ran more directly counter to the prepossessions of naturalists twenty years ago than this. And such prepossessions were very excusable, for there was undoubtedly a great deal to be said, at that time, in favour of the fixity of species and of the existence of great breaks, which there was no obvious or probable means of filling up, between various groups of organic beings.

For various reasons, scientific and unscientific, much bad been made of the hiatus between man and the rest of the higher mammalia, and it is no wonder that issue was first joined on this part of the controversy. I have no wish to revive past and happily forgotten controversies, but I must state the simpie fact that the distinctions in cerebral and other characters, which were so hotly affirmed to separate man from all other animals in 1860, have all been demonstratcd to be non-existent, and that the contrary doctrine is now universally accepted and taught.

But there were other cases in which the wide structural gaps asserted to exist between one group of animals and a nother were by no means fictitious; and, when such structural breaks were real, Mr. Darwin could account for them only by supposing that the intermediate forms which once existed had become extinct. In a remar':able passage he says :-

"We may thus account cven for the distinctness of whole classes from each othcr-for instance of birds from all other vertebrate animals - by the belief that many animal forms of life have been utterly lost, through which the carly progenitors of birds were formerly connected with the carly progenitors of the other vertebrate classes." ${ }^{3}$

Adverse criticism made merry over such surgestions as these. Of course it was easy to get out of the difficulty by supposing extinction; but where was the slightest evidence that such intermediate forms between birds and reptiles as the hypothesis required crer existed? And then probably followed a tirade upon this terrible forsaking of the paths of "Baconian induction."

But the progress of knowledge has justified Mr. Darwin to an extent which could hardly have been anticipated. In 1862, the specimen of Archaoptcryx, which until the last two or three years has remained unique, was discovered; and it is an animal which, in its leathers and the greater part of its organisation, is a veritable bird, while, in other parts, it is as distinctly reptilian.

In 1868 , I bad the honour of bringing under your notice, in this theatre, the results of investigations made, up to that time, into the anatomical characters of certain ancient

" "Origin of Species,", ec. r, p. 457.

3 "Origin of Species,", ed. I, p. 43 1. 
reptiles, which showed the nature of the modifications in virtue of which the type of the quadrupedal reptile passed into that of the bipedal bird; and abundant confirmatory evidence of the justice of the conclusions which I then laid before you has since come to light.

In 1875, the discovery of the toothed birds of the cretaceous formation in North America, by Prof. Marsh, completed the series of transitional forms between birds and reptiles, and removed Mr. Darwin's proposition that "many animal forms of life have been utterly lost, through which the early progenitors of birds were formerly connected with the early progenitors of the other vertebrate classes," from the region of hypothesis to that of demonstrab!e fact.

In 1859 , there appeared to be a very sharp and clear hiatus between vertebrated and invertebrated animals, not only in their structure, but, what was more important, in their development. I do not think that we even yet know the precise links of connection between the two; but the investigations of Kowalewsky and others upon the development of Amphioxus and of the Tunicata prove beyond a doubt that the differences which were supposed to constitute a barrier between the two are non-existent. There is no longer any difficulty in understanding how the vertebratc type may have arisen from the invertebrate, though the full proof of the manner in which the transition was actually cffected may still be lacking.

Again, in 1859 , there appcared to be a no less sharp separation between the two great groups of flowering and flowerless plants. It is only subsequently that the series of remarkable investigations inaugurated by Hofmeister has brought to light the extraordinary and altogether unexpected modifications of the reproductive apparatus in the Lycopodincea, the Rhisocarpea, and the Gymnospermea, by which the ferns and the mosses are gradually connected with the Phanerogamic division of the vegetable world.

So, again, it is only since $18 ; 9$ that we have acquired that wealth of knowledge of the lowest forms of life which demonstrates the futility of any attempt to separate the lowest plants from the lowest animals, and shows that the two kingdoms of living nature have a common borderland which belongs to both or to neither.

Thus it will be observed that the whole tendency of biological investigation since 1859 has been in the direction of removing the difficulties which the apparent breaks in the serics creatcd at that time; and the recognition of gradation is the first step towards the acceptance of evolution.

As another great factor in bringing about the change of opinion which has taken place among naturalists, I count the astonishing progress which has been made in the study of embryology. Twenty years ago, not only were we devoid of any accurate knowledge of the mode of devclopment of many groups of animals and plants, but the methods of investigation were rude and imperfect. At the present time there is no important group of organic beings the devclopment of which has not been carefully stidied, and the modern methods of hardening and section-making enable the cmbryologist to determine the nature of the process in each case, with a degree of minuteness and accuracy which is truly astonishing to those whose memories carry them back to the beginnings of modern histology. And the results of these embryological investigations arc in complete harmony with the requirements of the doctrine of Evolution. The first beginnings of all the higher forms of animal life are similar, and however diverse their adult conditions, they start from a co:mmon foundation. Moreover the process of development of the animal or the plant from its primary egg or germ is a truc process of evolution-a progress from almost formless to more or less highly organised matter, in virtue of the propertics inherent in that matter.

To those who are familiar with the process of development all a priori objections to the doctrine of biological evolution appear childish. Any one who has watched the gradual formation of a complicated animal from the protoplasmic mass which constitutes the essential element of a frog's or a ben's egg has had under his eyes sufficient evidence that a similar evolution of the animal world from the like foundation is, at any rate, possible.

Yet another product of investigation has largely contributed to the removal of the objections to the doctrine of Evolution current in 1859 . It is the proof afforded by successive discoveries that Mr. Darwin did not overestimate the imperfection of the geological record. No more striking illustration of this is nceded than a comparison of our knowledge of the mammalian fauna of the Tertiary epoch in 1859 with its present condition. M. Gaudry's researches on the fossils of Pikermi were published in 1868, those of Messrs. Leidy, Marsh, and Cope on the fossils of the Western Territories of America, have appeared almost wholly since 1870 ; those of $\mathrm{M}$. Filhol, on the phosphorites of Quercy, in 1878. The general effect of these investigations has been to introduce us to a multitude of extinct animals, the existence of which was previously hardly suspected; just as if zoologists were to become acquainted with a country, hitherto unknown, as rich in novel forms of life, as Brazil or South Africa once were to Europeans. Indecd the fossil fauna of the Western Territories of America bids fair to exceed in interest and importance all other known Tertiary deposits put together; and yet, with the exception of the case of the American tertiaries, these investigations bave extended over very limited areas, and at Pikermi were confined to an extremely small space.

Such appear to me to be the chief events in the history of the progress of knowledge, during the last twenty years, which account for the changed feeling with which the doctrine of Evolution is at present regarded by those who have followed the advance of biological science in respect of those problems which bear indirectly upon that doctrine.

But all this remains mere secondary evidence. It may remove dissent, but it does not compel assent Primary and direct evidence in favour of Evolution can be furnished only by palæontology. The geological record, so soon as it approaches completeness, must, when properly questioned, yield cither an affirmative or a negative answer; if evolution has taken place, there will its mark be left ; if it has not taken place, there will lic its refutation.

What was the state of matters in 1859 ? Let us hear Mr. Darwin, who may be trusted always to state the case against himself as strongly as possible.

"On this doctrine of the extermination of an infinitude of connecting links between the living and extinct inhabi 
tants of the world, and at each successive period between the extinct and still older species, why is not every geological formation charged with such links? Why does not every collection of fossil remains afford plain evidence of the gradation and mutation of the forms of life? We meet with no such evidence, and this is the most obvious and plausible of the many objections which may be urged against my theory." 1

Nothing could have been more useful to the opposition than this characteristically candid avowal, twisted as it immediately was into an admission that the writer's views were contradicted by the facts of palæontology. But, in fact, Mr: Darwin made no such admission. What he says in effect is, not that palæontological evidence is against him, but that it is not distinctly in his favour; and without attempting to attenuate the fact, he accounts for it by the scantiness and the imperfection ;of that evidence.

What is the state of the case now, when, as we have seen, the amount of our knowledge respecting the mammalia of the Tertiary epoch is increased fifty-fold, and in some directions even approaches completeness?

Simply this, that if the doctrine of Evolution had not existed palæontologists must have invented it, so irresistibly is it forced upon the mind by the study of the remains of the Tertiary mammalia which have been brought to light since 1859 .

Among the fossils of Pikermi, Gaudry found the successive stages by which the ancient civets passed into the more modern hyænas; through the Tertiary deposits of Western America, Marsh tracked the successive forms by which the ancient stock of the horse has passed into its present form ; and innumerable less complete indications of the mode of evolution of other groups of the higher mammalia have been obtained.

In the remarkable memoir on the Phosphorites of Quercy, to which I have referred, M. Filhol describes no fewer than seventeen varieties of the genus Cynodictis, which fill up all the interval between the viverine animals and the bear-like $\operatorname{dog}$ Amphicyon; nor do I know any solid ground of objection to the supposition that in this Cynodictis-Amphicyon group we have the stock whence all the Viveridæ, Felidæ, Hyænidæ, Canidæ, and perhaps the Procyonidæ and Ursidæ, of the present fauna have been evolved. On the contrary, there is a great deal to be said in its favour.

In the course of summing up his results, M. Filhol observes $^{2}$ :-

"During the epoch of the phosphorites, great changes took place in animal forms, and almost the same types as those which now exist became defined from one another.

"Under the influence of natural conditions of which we have no exact knowledge, though traces of them are discoverable, species have been modified in a thousand ways: races have arisen which, becoming fixed, have thus produced a corresponding number of secondary species."

In 1859, language of which this is an unintentional paraphrase, occurring in the "Origin of Species," was scouted as wild speculation ; at present, it is a sober statement of the conclusions to which an acute and criticallyminded investigator is led by large and patient study of the facts of palæontology. I venture to repeat what I have said before, that, so far as the animal world is conI "Origin of Species, ed. x. p. 463 . 2 This passage was omitted in the delivery of the lecture. cerned, Evolution is no longer a speculation, but a state. ment of historical fact. It takes its place alongside of those accepted truths which must be taken into account by philosophers of all schools.

Thus when, on the first day of October next, the "Origin of Species" comes of age, the promise of its youth will be amply fiulfilled; and we shall be prepared to congratulate the venerated author of the book, not only that the greatness of his achievement and its enduring influence upon the progress of knowledge have won him a place beside our Harvey; but, still more, that, like Harvey, he has lived long enough to outlast detraction and opposition, and to see the stone that the builders rejected become the head-stone of the corner.

T. H. HuXLEY

\section{ON MULTIPLE SPECTRA}

" Nunc age, quo motu genitalia materiai Corpora res varias gignant, genitasque resolvant Et qua vi facere id cogantur."

$$
\text { Lucretius, ii., 6I-2. }
$$

“ Prima moventur enim per se primordia rerum : Inde ea, quæ parvo sunt corpora conciliatu, Et quasi proxima sunt ad vireis principiorum, Ictibus illorum cæcis impulsa cientur

Ipsaque, quæ porro paulo maiora, lacessunt." Lacretius, ii. I32-6.

"It is conceivable that the various kinds of matters, now recognised in different elementary substances, may possess one and the same ultimate or atomic molecule existing in different conditions of movement.

"The essential unity of matter is an hypothesis in harmony with the equal action of gravity upon all bodies."-Grahan's Researches, p. 299.

$\mathrm{T}$ a recent paper ${ }^{1} \mathrm{I}$ showed that a study of the minute 1 anatomy of spectra, both terrestrial and celestial, forces upon us the conclusion that both in the eleciric arc and in the hottest region of the sun the so-called chemical elements behave after the manner of compound bodies.

I then dealt more especially with the question of the basic lines in the various spectra, and it is clear that if, at any one temperature, there be some lines only truly basic in the spectrum of any element, we at once divide the lines visible at that temperature into two groups, those which are basic and those which are not. This would give a compound origin to the lines, and this is the rea! point.

It is now years ago since the view was first held that the elementary bodies had double spectra, that is, that each, or at all events several, under changed conditions of temperature or electric tension, gave us now a fluted spectrum and now one composed of lines.

I glimpsed the idea some time afterwards that the line spectrum was in its turn in all probability a complex: whole, in other words that it was the stimmation of the spectra of various molecular groupings.

Recent work has to my mind not only shown that this is true, but that in the case of many bodies the complexity, and therefore the number, of the molecular groupings which give rise to that compound whole called a line spectrum, is considerable.

It is therefore important from my point of view to reconsider the evidence on which the assertion that the

I "On the Necessity for a N New Departure in Spectrum Analysis" (NATURe, vol. xxi. p. 8). 